\title{
SIGER OF BRABANT, AUTHOR OF THE ANONYMOUS QUESTIO DE CREATIONE EX NIHILO
}

\author{
LISA DEVRIESE* \\ KU LEUVEN
}

$\boldsymbol{\varphi}$

Introduction

Siger of Brabant, the thirteenth century philosopher born in the Low Countries, is credited with a number of works, such as treatises on the soul, on the world, and logical and natural questions. Since recently, we can add to this list another work, i.e. the Questio de creatione ex nihilo. ${ }^{1}$ This anonymous work was attributed to Siger of Brabant by some scholars in the $20^{\text {th }}$ century, but Andrea Aiello is the first one to edit this QDC in its entirety and give decisive arguments for this authorship. It is precisely at this edition we will take a closer look in this review. ${ }^{2}$ This new book fits perfectly within the field of study of the editor. The QDC can be found in only one manuscript, bound together with other texts of Parisian masters of the faculty of Arts. It is precisely on this manuscript that the editor has published several books and articles. ${ }^{3}$ In that way, the content of this interesting manuscript, which can be attributed to Godfrey of Fontaines, is gradually disclosed.

\footnotetext{
Ph. D. fellowship of the Research Foundation - Flanders (FWO) at KU Leuven.

Following the editor's practice, Questio de creatione ex nihilo will be abbreviated as QDC.

Andrea Aiello (ed.), Sigeri di Brabante. Questio de creatione ex nihilo, ms. Paris BnF lat. 16297, f. 116rbvb): Edizione, paternità e cronologia, (Millennio Medievale 106 - Testi 25), Firenze: Sismel. Edizioni del Galluzzo, 2015.

3 Andrea Aiello, 'Notule de scientia theologie' (mss. Paris, Nat. lat. 15355, f. 40r mg. inf. - Paris, Nat. lat. 16297, ff. 231v-232v): Edizione critica, cronologia, paternità, Roma: Pontificia Università della Santa Croce, 2003. Robert Wielockx - Andrea Aiello, Goffredo di Fontaines aspirante baccelliere sentenziario: le autografe 'Notule de scientia theologie' e la cronologia del ms. Paris BnF lat. 16297, (Corpus Christianorum. Autographa Medii Aevi, 6), Turnhout: Brepols, 2008. Robert Wielockx - Andrea Aiello, 'La versione del Quodlibet IV (qq. 7-8) di Enrico di Gand nel ms. Paris BnF lat. 16297', Documenti e studi sulla tradizione filosofica medievale 19 (2008), pp. 371-499.
} 
The study on the QDC is composed of two main parts, a division which we will adopt in this paper. The first part of the book consists of the first edition of the QDC, which has as main question 'Utrum aliquid possit esse genitum sive factum ex nihilo seu non ex aliquo'. The second part of the book is a thorough study in order to attribute this text, which has no attribution in the preserved manuscript, to Siger of Brabant. The editor will explore the authorship in different ways: by means of external critique (i.e. the chronology of the text and codicological aspects of the manuscript), elimination of possible authors based on doctrinal content, comparing the body of ideas of the QDC with works of Siger of Brabant, examining sources and, finally, the style of the work. With abundant arguments, the editor will be able to attribute this work with certainty to the philosopher Siger of Brabant.

The purpose of this paper is to critically review this recently published book, more precisely to accentuate the good aspects and indicate what is missing or not clear. We will particularly concentrate on the edition and the arguments of chronology and not so much on the content of the QDC itself.

However, for a correct understanding of the text, I will briefly recapitulate the main thesis of the question. ${ }^{4}$ The question deals with the creatio ex nihilo, which Siger will deny. He makes a distinction in terminology between the sentences 'not made from something' (non esse factum ex aliquo) and 'made from nothing' (factum ex nihilo). The first one denies that something has the nature of a material cause for the heavens, the second affirms that nothing or non-being has order and causality. This second possibility, the ex nihilo, is false. Siger claims that heavens, as well as the production of the whole being, are not made from something and this is not through change (since change requires a substrate to produce out).

At the end of the question, he makes more explicit what the word '(non-) being' is understood to mean. What of its own nature is impossible to be, and has no potency for being, can receive from nothing its being and is therefore pure non-being (purum non esse) and absolute non-being (non ens simpliciter). This is contrasted with the example of Socrates, who is a being in potency of non-being at some time, which is different. He is therefore not absolute being and he will be only for a certain amount of time. According to some philosophers, Siger claims, non-being receives being by an emanating agent. But this is not possible: pure non-being cannot change into being, not by itself, not by the potency of an agent (an agent can only make when something has the possibility for being). This nature of non-being or nothing leads him to the conclusion that there is no such thing as a creatio ex nihilo, because nothing can never receive being.

4 However, the order of the arguments in the text is not followed. The text presents itself in the typical quaestio-structure, i.e. arguments pro, arguments contra, followed by the solution of the philosopher himself. 
Siger of Brabant, author of the anonymous Questio de creatione ex nihilo

\section{Edition of the 'Questio de creatione ex nihilo'}

\section{Edition of the Latin text}

The QDC is preserved in only one manuscript, ms. Paris BnF lat. 16297, f. $116 \mathrm{rv} .{ }^{5}$ It is quite unfortunate that there are no other manuscripts extant, since this specific manuscript belonged to Godfrey of Fontaines. Throughout the book it is revealed that this scholar had the tendency to shorten texts and give abbreviated versions of the original. One could therefore ask the question to what extent the questio in this manuscript is similar to the original. It is unfortunate that the editor does not indicate if he went in search for other manuscripts which contain this treatise. It is not impossible that other manuscripts will come to the surface, now that there are many projects of disclosing and digitalizing manuscripts. The text can be hidden under another title as well. In this specific manuscript, it was not indicated separately in the index at the beginning that there was a question on creation.

Because of the fact that there is only one manuscript to base his edition on, the editor did not deem it fit to elaborate on editorial principles. What concerns the orthography, he probably followed the spelling of the manuscript. He does intervene in the text what concerns punctuation and what concerns the structure of the argumentation, by adding 'solutio' or by numbering the different arguments pro and contra. Both interventions make the treatise more readable and understandable for modern readers. The edition is accompanied by an Italian translation, which is useful for an audience not familiar with medieval Latin.

\section{Critical apparatus}

The critical apparatus at the bottom of each page of the edition is limited since we only possess one version of the text. In the apparatus, the editor mentions the words and passages which are written in the margin, are erased, etc., accompanied by the letter ' $G$ ', referring to Godfrey of Fontaines, who wrote down the text. This can give the - incorrect - impression that these marginal notes are added by a second hand $(G)$ at a later stage, since this was not explained earlier. However, everything is written in one single hand. The reason for this addition could be found in the fact that the entire manuscript of Paris is written in different hands ${ }^{6}$ and in this way, this edition must be seen in the larger tradition of editing this manuscript.

\footnotetext{
5 This manuscript can be consulted online: http://gallica.bnf.fr/ark:/12148/btv1b90666175 /f117.item. A colour reproduction of the folia concerned is added in the book.

6 Wielockx - Aiello, Goffredo di Fontaines, pp. 63-85.
} 
Source apparatus

Beside the critical apparatus, there is a second, much larger, apparatus for the sources. In this apparatus, the editor firstly wants to localize the explicit references made in the text (e.g. when referred to the Metaphysics of Aristotle), and secondly - and this is a harder task - he tries to figure out to which philosophers or works the author of the QDC implicitly refers to or gives comments on. Therefore, this apparatus is vitally important to examine the dialogue between several philosophers. However, it is unfortunate that the editor did not write anything on his investigation of the sources, how he dealt with it and what were his objectives. Are the sources mentioned really sources on which Siger drew, or only passages where similar thoughts can be found?

\section{Chronology and authorship of the Questio}

Since there is no explicit attribution in the manuscript to any author, the editor tries to come to decisive arguments if it could be Siger, as previously proposed by other scholars. It is not the purpose of this article to repeat these arguments, we will only single out some passages.

\section{First problem with dating}

In determining the terminus a quo, Aiello mentions that the author of the QDC refers to the De causa motus animalium and therefore attests the existence of Moerbeke's translation of this Aristotelian treatise. However, there is a second, anonymous Latin translation of this work, of which no copies are extant, but we only know this indirectly through Albert Magnus' De principiis motus processivi. A hypothetical reconstruction of this translation exists. ${ }^{7}$ This translation is now lost since there are no manuscripts containing the text, but to what extent Siger could have known this text, is impossible to determine. Aiello mentions this anonymous translation in a footnote but dismisses the idea that Siger could have

\footnotetext{
Pieter De Leemans (ed.), De motu animalium. Fragmenta translationis anonymae (Aristoteles Latinus, XVII 1.III), Turnhout: Brepols 2011. Albertus Magnus mentions in his work that he found a manuscript of this translation during his trip in Italy (Campania), which can be situated in 12567. Therefore, it is older than the translation of Moerbeke, but when exactly, cannot be determined, see De Leemans, De motu animalium, p. xviii. The passage in which he mentions this translation: 'De modo ergo huius motus, licet iam in libro De motibus animalium hoc quod nos sensimus, tradiderimus, tamen quia postea in Campania iuxta Greciam nobis agentibus pervenit ad manus nostras libellus Aristotelis De motibus animalium, etiam hic ea que tradidit, interponere curavimus ut sciatur si in aliquo ea que ex ingenio proprio diximus, deviant a Perypatheticorum principis subtilitate', see De Leemans, De motu animalium, p. x.
} 
Siger of Brabant, author of the anonymous Questio de creatione ex nihilo

used it, since it seems that it was not used by other authors. ${ }^{8}$ The translation of Moerbeke (situated around 1260) was a first terminus a quo for the QDC, but this does not seem to be a firm argument. It is indeed possible, but it cannot be determined with certainty that the author of the QDC used Moerbeke's translation, all the more because he does barely quote explicitly. of all the works of Aristotle mentioned in the source apparatus, there was always more than one translation circulating. More precisely, of the Metaphysica, Physica, De sensu and De caelo, there was always a translation of Moerbeke and one (or more) anonymous translation(s). Since Moerbeke used and revised these older translations, both versions are highly similar (at least in the passages quoted in the QDC) and therefore it is impossible to determine which version Siger used. That is the reason why the editor mentions the different version (as far as they have been edited) in his source apparatus. However, since no decisive argument can be given that the author of the QDC used Moerbeke, this translation cannot be used as an argument for the chronology of the text.

\section{Second problem with dating}

In trying to determine a time period in which the text was composed, the editor uses the source material of the QDC as mentioned in the source apparatus. The date of these works will be a terminus ad quem and a quo for the QDC. ${ }^{9}$ However, again, the editor does not explain his principles and therefore does not mention why exactly he singles out five works for his study and leaves the others aside. As can be seen in the source apparatus, there are more sources than the selected ones. The editor focuses on works of Thomas Aquinas, who, though not explicitly mentioned, is omnipresent in the QDC.

In his argumentation for the dating on the basis of source material, he fixes a date on each work in order to narrow down the possible time period. However, the question presents itself how dating a work of centuries ago can be an exact science and to what extent we can rely on this kind of information. Of the works of Thomas Aquinas, Aiello mentions three of them: the Summa Theologiae (Prima Pars), which moves the terminus a quo to 1268/1269; the Sentencia libri De sensu et sensato (terminus a quo to 1269) and the Sup. VIII Phys. (terminus a quo to 1269/1270). ${ }^{10}$ However, if one consults different secondary literature on the

8 Aiello, Sigeri di Brabante, p. 27, n. 17.

9 A small typographic error has crept in. In Aiello's study, (e) is missing, and the list goes from (d) immediately to (f), see p. 39.

10 For each of the quoted works, the editor shows similarities in content, in order to convince that this work was used by the QDC. However, the arguments for this specific work are not very convincing, especially where he sees a similarity in terminology and phrasing between both works (see p. 37). The quoted passages seem to offer just standard terminology, given the fact 
dating of these treatises, once can see that it is difficult to produce conclusive evidence and to agree on the date of production. E.g. for the Sup. VIII Phys., Torrell - who wrote a work on the dating of Thomas Aquinas' works - presumes that it was written in 1268/1269 instead of 1269/1270. ${ }^{11}$

Since Aiello did not specify why he only studied the dating of five works, we will take a closer look at the other works which are mentioned in the source apparatus (assuming that these are indeed sources and not treatises with only similar or contrasting ideas) to evaluate if these give us another perspective. For the references to Aristotle, it is not clear which translation the author of the QDC used, the one of Moerbeke or the older one (cf. supra), but anyhow, Moerbeke's translations are to be situated around 1260 .

The dating of the other works of Thomas Aquinas (relying on Torrell) are: ${ }^{12}$ Super sententiis (1252/1257), Sup. Metaph. (dating this work is problematic, but it certainly is before 1272/3), De potentia (1265/1266), De eternitate mundi (problematic as well, ranging from 1255 till 1271), De substantiis separatis (later than the first half of 1271), Summa contra gentiles (1259/1265). Since Aiello dated the QDC in the time period of 1268/1269 at the earliest and 1277/1278 at the latest, and probably between 1270/1271 and March 7, 1277, the only work which can slightly change this date is the De substantiis separatis. However, the references to this work are anything but literal and the same content appears in other treatises as well. Therefore, it is absolutely uncertain that this work was indeed a direct source for the author of the QDC. The given data may not be absolute, it is just an indication that dating works is not an exact science and cannot be used as conclusive evidence, especially not when the dates are following each other closely.

Besides these treatises, Avicenna and Averroes are referred to as well, but these works were already known in the Latin West by the first half of the $13^{\text {th }}$ century. ${ }^{13}$ In the source apparatus, Albert the Great's De causis et processu

that both works are dealing with the creation of the world. The words - which the editor marks as significant - are not even in the same order or in the same connection with other words. E.g. in the Sup. VIII Phys. "quamvis Platonici dicant Platonem sic dixisse caelum esse factum, inquantum habet principium activum sui esse, non autem ita quod habeat durationis principium' (italics are taken over as in the book) and in the QDC 'constat quod celum factum est etiam secundum opinionem omnium philosophorum cum causam sui esse habeat'. Indicating 'celum factum est', which is a quite standard expression, in a work which deals with the creation of the world does not seem convincing and can be referring to any work. However, the other arguments given, i.e. quoting the same sources and the theory on emanation, are on the other hand convincing.

11 Jean-Pierre Torrell, Initiation à saint Thomas d'Aquin: sa personne et son œuvre, (Vestigia - Pensée antique et médiévale), Fribourg: Editions Universitaires de Fribourg, 1993, p. 499.

12 In order of appearance in the source apparatus.

13 Dag Nikolaus Hasse, Latin Averroes Translations of the First Half of the Thirteenth Century, Hildesheim - Zürich - New York: Olms, 2010. 
Siger of Brabant, author of the anonymous Questio de creatione ex nihilo

universitatis is mentioned as well, which has a conjectured date between 1265 and $1272 .{ }^{14}$ Again, the source apparatus mentions another work as well for the very same sentence.

Finally we have the works of Boethius of Dacia, but his works are not yet studied as extensively as the works of Thomas Aquinas with regard to dating; therefore, these are more uncertain. Except the work Aiello discusses, two other of his treatises are mentioned in the apparatus, i.e. De eternitate mundi (which is estimated around $1270^{15}$ ) and Sup. Lib. Phys. (no exact date available).

All in all, we can say that the quoted treatises in determining the exact date of the QDC are randomly chosen. They assert the hypothesis of the editor, but he does not give any indication what the dating of the other works are, or why he selected only these five. Are these more important sources? Are these the only certain direct sources? It must be admitted that this method is interesting to fix a date to the treatise and it has certainly value, but at times it seems that the editor walks on thin ice.

However, the overall chronology is not liable to be pushed aside by these adjustments. The time frame is still consistent with the time period Siger was teaching in Paris.

\section{Problems with external evidences}

After giving evidence for the chronology of the text, the editor gives two other small arguments in favour of the authorship of Siger of Brabant, before turning to the second part of his argumentation, i.e. the elimination of other possible authors. Of these two smaller arguments, he himself states that 'questi dati non sono sufficienti a provare la paternità sigeriana della $Q D C$ ', ${ }^{16}$ but that they do have argumentative value. However, it seems that these two arguments are problematic and simply cannot be seen as arguments.

The first is the fact that Godfrey of Fontaines devoted a lot of attention in his first manuscripts (i.e. mss. Paris BnF lat. 15819, 16297 and 16096) to scholars of the Faculty of Arts of Paris; especially Siger of Brabant and Boethius of Dacia occupy an important place. In ms. 16297 (the manuscript with the QDC), and more specifically in this specific part of the manuscript, there is the highest concentration of works of Siger of Brabant, which is, according to Aiello, an argument in favour of the hypothesis that Siger is the author of the QDC.

14 Vincent Guagliardo et al. (eds.), St. Thomas Aquinas. Commentary on the Book of causes, Super librum de causis exposition, Washington DC: Catholic University of America Press, 1996, p. xi.

15 Niels Jørgen Green-Pedersen (ed.), Boethii Daci Opera. Topica - Opuscula. De aeternitate mundi. De summon bono. De somniis (Corpus Philosophorum Danicorum Medii Aevi, VI, 2), Copenhagen: Gad, 1976, p. xxii.

16 Aiello, Sigeri di Brabante, p. 45, 47. 
However, if some works in this manuscript are of Siger, it does not follow automatically that the anonymous question is his as well, not even as an argument supporting the hypothesis. In a concrete manner, there are eight works of at least sixteen works in this manuscript, attributed to Siger of Brabant, which is only half.

The second argument is when the editor sees codicological similarities between the QDC and the Sup. Metaph. (a work of Siger in the same manuscript). There were already similarities between the two treatises on the basis of content, and both are to be found in the same part of the manuscript (the manuscript is divided in seven distinct parts), and now there is a codicological relationship as well. In the margin of both texts the notation '.a.' and '.b.' can be found, as an indication that the order of the text should be corrected and that the arguments in the text must change places. Apparently, in both texts there was the need to intervene since the model Godfrey of Fontaines used, lacked order. Again, he repeats that this alone is not enough to prove that Siger is the author, but according to me, this can never be used as an argument. Firstly, the fact that there is the same marginal notation, is caused by the copyist, since it is his custom to indicate a change like this (and both texts are written by the same hand, i.e. that of Godfrey). ${ }^{17}$ This happens independently from the content or the author of the original treatise, since it is the copyist's habit, how he corrects errors. Secondly, if it does say something about the model - it could be a mistake on the part of the copyist as well - it does not assert something on the authorship. Unless the editor silently presumes that this model only contained works of Siger, but there are no arguments of this. Besides, both texts having a disordered model does not mean that both texts have the same disordered model. Therefore, this seems an argument where he starts with what he wishes to conclude, i.e. that both texts are from Siger, and from this point on, he tries to find similarities between both texts.

\section{Problem with elimination}

Although the arguments of the elimination are very convincing, the same problem reappears - as was the case for the source apparatus -, namely, that the editor does not explain his principles. He eliminates six medieval scholars (of which two anonymous ones) on the basis of doctrinal differences, but does not explain why precisely those six and not more or less. Are these the only ones of this time period that had similar views on the creation of the world? Are these the only ones that geographically can be related to this text? It is difficult to

17 Aiello, Sigeri di Brabante, p. 44. 
Siger of Brabant, author of the anonymous Questio de creatione ex nihilo

encourage further research, if one does not know what were the criteria for selection or what has been examined already and did not produce any results.

Besides these questions that can be raised with this chapter, it is worth mentioning that the doctrinal elimination in itself is cogent. It is demonstrated elaborately that these six scholars had contrasting views. Based on what they wrote on, for example, the heavens, the production of the whole being, the precise meaning of the preposition 'ex' and the nature of a non-being, it is clear that these scholars cannot be the author of this question.

Together with the elimination of possible authors based on the doctrinal content, the subsequent chapter, concentrating on other treatises of Siger, give the most convincing proof. In this chapter, the editor examines whether the body of thoughts of the QDC is compatible with the ideas expressed in Siger's other works. What can be deduced from the enumeration of the analogies, is the fact that almost every doctrinal aspect of the QDC recurs in one or another treatise of Siger, e.g. the topics of transmutation, the heavens, the pure non-being, the nature of the human being, the fact that we cannot speak of a creatio ex nihilo and that the preposition ' $e x$ ' has a very distinct meaning, etc. Some parallels are even literal. At the end of the study, several lists are given with parallels between the QDC and other works, to support the conclusion even more.

\section{Possible lines of thinking}

Although the book gives extensive evidence for the authorship of Siger of Brabant by studying the question in detail, the history of the text itself is left aside. Therefore, possible questions to be raised are how this treatise was received in later times. Are there any authors who refer to this text, and which name or title did they use, or did really no one use this treatise? If so, was the condemnation of 1277 the only reason for this disappearance? And if not used directly, are there no secondary sources which mention this text, such as repertories of medieval libraries? These questions were of course not within the scope of the published book, but could nevertheless give additional information and could be interesting for later research.

\section{Conclusion}

The elements touched upon in this paper only nuanced certain arguments or showed where the editor should have been more elaborate in his explanation, but we must not forget that the overall line of arguments is impressive and that the editor certainly succeeded in his primary goal. It must be stressed that the conclusion that Siger of Brabant is the author of the Questio de creatione ex nihilo is very convincing. The editor came to this conclusion by means of chronology, 
elimination, comparing ideas of the QDC with ideas of Siger, and studying the style. This broad and thorough approach makes this work very interesting and it is certainly an important contribution to scholarship. 